\title{
The Journal of Travel and Tourism Marketing
}

\section{The Impacts of Foot and Mouth Disease on a Peripheral Tourism Area: the Role and Effect of Crisis Management.}

\author{
Wilson Irvine \\ Aberdeen Business School \\ The Robert Gordon University \\ Garthdee Road \\ ABERDEEN \\ U.K. AB10 9NU Tel: 01224263013 \\ w.irvine@rgu.ac.uk
}

Alistair R Anderson

Aberdeen Business School

The Robert Gordon University

ABERDEEN

U.K.

AB10 9NU Tel: 01224263883

\begin{abstract}
This study reports on the consequences of endemic cattle and sheep disease (2001) on two separate areas on the tourist industry; a) the Grampian Region of Scotland (indirectly affected) and b) Cumbria in England, (directly affected), and secondly on the effects of various crisis management strategies to alleviate the ensuing problems in both areas. Data were collected by a survey of a sample of 200 tourism orientated SME operators in Grampian and 170 businesses in Cumbria.

The results show two forms of impact caused by the disease, direct and those less obvious or tangible. Direct impact was the dramatic loss of trade, most dramatically experienced by the lack of tourists visiting the areas. Indirect effects included loss of supply, change to the product offered and cuts in future investment. In the combination of these impacts, it was clear that the effects would have longevity far beyond the period of the actual crisis. Although the actual presence of the disease was geographically limited in Grampian, the consequences rippled out to affect areas that had no direct connection. In Cumbria, the effects were only slightly more severe but the response more direct and initially effective. Significantly the data also demonstrated a perception of minimal effort by the government to limit the consequences to the farming industry especially in Grampian. We conclude that the tourist industry in peripheral regions is fragile and highly vulnerable to any external shocks. However, we also note the ability of small rural firm to respond to such catastrophes and to avert the worst impacts of crisis.
\end{abstract}




\section{The Impacts of Foot and Mouth Disease on a Peripheral Tourism Area: the Role and Effect of Crisis Management.}

\section{Introduction}

This paper examines the impact of the outbreak of Foot and Mouth disease in sheep and cattle on peripheral British tourism areas. The study considers two tourism areas, Grampian in the north of Scotland and Cumbria in the north of England. Whilst both can be conventionally described as peripheral, the Cumbria area was directly affected in the outbreak, with a high number of reported or suspected cases of the disease. In contrast, Grampian had no incidence of the disease, but was, nonetheless sorely affected by the adverse publicity. Our study suggests that we can make some general and some specific conclusions about this crisis. We find, for example, that tourism businesses in peripheral areas are particularly vulnerable to crisis. We note how government communication, directed to stopping the outbreak, resulted in a very high profile media presentation which, in possibly exaggerating the effect, actually amplified the impact. In specific terms, we note how some small businesses reacted quickly to the disaster by taking action to minimise the effects of the dramatic loss of business. In particular we observe how the presence of a "plan" seemed to avert the worst effects of catastrophe.

The first section briefly explores the nature of crisis to argue that disasters on the scale of the foot and mouth outbreak will inevitably become crisis for tourist firms. We explain this point by demonstrating that the demand for tourism is uniquely sensitive to the hedonistic and eudemonistic perceptions of pleasure seeking or happiness generation. Because these aspects are highly subjective perceptions of tourist destinations, any negativity impacts disproportionately. Moreover, the attraction of peripheral places appears to depend upon images. These images, the manifestations of what Lash and Urry (1994) call the economies Signs and Space seem to create the very attraction of tourist destinations. However, in the case of foot and mouth disease, the dramatic media images amplified the negativity. This section completes our theoretical overview and is followed by a brief account of the foot and mouth epidemic. We then present our survey data, which consists of three surveys. Two surveys took place in Grampian; survey A was conducted at the height of the disaster and reports on the anticipated crisis, whilst survey B reports on the actual effects taking account of the management of the crisis. The third survey was conducted in Cumbria and reports on the impact on business. We discuss the data in the light of perceptions and actions. The contribution of the paper is first to address the need identified by Okumus et al (2003) on the limitations of the existing literature on the impact of crisis on a tourist destination. More abstractly, we hope to contribute to a fuller understanding of the links between communication and crisis and to the role of planning in avoiding the worst impacts for rural small firms.

\section{The nature of crisis and disaster}

Faulkner (2001) comments that the casual observer exposed to the plethora of media that informs us, may believe that we live in an increasingly disaster prone world. GonzalezHerrero and Pratt (1998:85) note how the business environment is becoming more complex and unstable, hence signalling "an era of crises", whilst Richardson (1994) suggest that the world is more turbulent and crisis prone. Many attribute the apparent increase in disaster to the increasing complexity of the modern world, as for example, in Ulrich Beck's idea of Risk Society (1992). Others propose that the incidence of disaster may not be increasing in absolute terms, but merely that our heightened awareness of and on the global scale, the space-time compression, of Harvey (1980) simply make it appear so. Whichever may be the case, the role of media in transmitting signals, messages in McLuhan's sense, seems to play a 
pivotal role in our perception of disaster. Baudrillard (1998) suggests that the raw event (of disaster, in this case, becomes consumable when filtered, fragmented and reworked by the mass media into a finished product. This causes it to be conjured up, as Baudrillard describes it (1998:330), captured for consumption. Disaster makes news. However, as Ritchie (2003) comments, tourism, although increasing economically important, is highly susceptible to external factors.

Most poignant of disaster is the "natural" disaster, the earthquake, the flood or famine. Somehow man's puny efforts in the grim face of mother nature remind us of our limitations. But increasingly we have come to interpret, even understand, disaster as rather more than natural, and understand that it is the interface of man and nature which creates disaster. The impact of floods in Bangladesh are magnified by the limited resources available to mitigate. Nature is more contained in wealthy societies. Perhaps never entirely tamed, but sufficiently domesticated so that "natural" disaster only rarely manifests itself as widespread crisis to the extent of Selbst's (1978) definition of crisis, "Any action or failure to act that interferes with (an organisations) on-going functions, the acceptable attainment of its objectives, its viability or survival, or that has a detrimental personal effect as perceived by the majority". Yet this interface of man and nature helped to provide some understanding of the distinctions of and between disaster and crisis. Faulkner (2001) explains how Selbst's definition attributes crisis to the organisation, whilst disaster is used to refer to situations where the enterprise, or collection of enterprises in the case of tourist destinations, is confronted with sudden and unpredictable catastrophic changes over which it has no control. Stafford et al (2002) focus on the nature of business crisis. Such crises are defined by Lerbinger (1997) as an event that is severely detrimental to profitability or even survival. Stafford et al (2002) note that all such crisis share three common characteristics; suddenness, uncertainty and time compression. So a disaster becomes a crisis when the organisation(s) believe they cannot cope. Similarly, Kash and Darling (1988) define crisis as an event which threatens customers or employees and endangers financial status and future viability, Indeed, Carter (1991:23) defines disaster as an event, natural or man-made, sudden or progressive, which impacts with such severity that the affected community has to respond by taking exceptional measures. (Interestingly, Ritchie (2003) discussing Selbst's focus on perceptions of crisis, argues that if a "crisis" is perceived by stakeholders, a real crisis may emerge. Thus he highlights the role of perception management. Similarly, marketing and communications are crucial in what Gonzalez-Herrero and Pratt (1998) define as business crisis.) This distinction, or continuum between crisis and disaster, as Faulkner suggests, is useful because it highlights the human role, the agency, in mitigating, or not, the impact of disaster. Thus as Fink (1986) argues, if crisis planning and activities are effective the impact of the crisis can be limited.

The very notion of crisis, however, is not quite as cut and dried as the above suggests. Fink, (1986), for example, notes how, in business, managers are either in crisis, or in a state of precrisis. Others, including Okumus (2003), Adams (1998) Burnett (1998) and Davis and Walters (1998) emphasis the stages of crisis. These are broadly speaking, prodromal; acute chronic and crisis resolution. Our primary interest lies at the first stage, the prodromal, which Fink (1986) describes as the stage when it becomes evident that the crisis is inevitable. It is at this stage that agency is most likely to be most influential in shaping the outcomes of the crisis. Thus this interplay between disaster, action and crisis forms the basis of our research question. Drawing on the literature described above we propose that disaster and crisis and its impact can be modelled as a linear progression with two possible outcomes of catastrophe or control of the effects. Seen this way the role of agency in crisis, in terms of preparedness and appropriate responses to disaster, determines the impact of the disaster.

$$
\text { Disaster }>\text { Crisis }>\text { Catastrophe }
$$


Thus our questions surrounding the foot and mouth outbreak centre on what and how agency, in the form of the small business owners, professional bodies and state and local authorities responded to the disaster. As Bennett et al (2003) argued, because of their resilience and flexibility, small businesses should be encouraged and supported in the business environment. However, to complete our theoretical framework to approach this question we require to have an appreciation of the forces of attraction or repulsion applied to tourist destination.

\section{The brittleness of tourist peripheral destination image}

Brown and Hall (1999) describe a peripheral area as one which suffers geographic isolation, distant from core spheres of activity, poor access to and from markets. Such areas, they claim, are characterised as economically marginalised with much of the business activity confined to micro-business. Peripherality has been viewed as the biggest problems for tourism, being held responsible for the increasing amount of difficulties being experienced within the industry (Baum, 1991) and is most often viewed as the most consistent policy issue within coldclimate areas. A peripheral area is seen as an area of remote geographical isolation that is far away from central areas of activity, with poor infrastructure meaning access is difficult (Brown et al 2001). But as Wanhill (1997), notes the European Union's Maastricht Treaty acknowledged that tourism could reduce regional disparities. Taken together we see the importance of tourism for the peripheral place, highly dependent on the "difference" of image from the core, but equally we see how it appears to depend on a positive image. Tourism image is defined by many authors as an individual's overall perception or total set of impressions about a place (Fakeye and Crompton, 1991; Hunt, 1975; Phelps, 1986), or as the mental portrayal of a destination (Alhemoud and Armstrong, 1996; Crompton, 1979). Such images are the manifestations of the social construction of a place. In other words, as Carter (1998) puts it, the symbolic contributes to the sense of place. The image of a destination consists, therefore, of the subjective interpretation of reality made by the tourist. There is now considerable evidence (Crompton and Ankomah, 1993; Gartner, 1989; Kent, 1990) of the influence of tourism image on the choice of holiday destination. Places with stronger positive images will have a higher probability of being included and chosen in the process of decision making. Gonzalez-Herrero and Pratt (1998) even suggest that people must be informed about a travel destination and be interested in going there, before a tourist market can be created. Shultz (1970) talks about the stocks of knowledge of a phenomenon acquired intersubjectively by individuals; formed through organic representations produced by media, education, government and other institutions. Tiefenbacher et al (2000) argue that such perceptions are generated by advertisement, movies and word of mouth. Places are transformed into a tourist site through the system of symbolic and structural processes. As Harvey (1989:293) puts it so well, "Mass television ownership coupled with satellite communication make it possible to experience a rush of images almost simultaneously, collapsing the world's spaces into a series of images on a television screen..........mass tourism".

Rurality, and its attraction as a destination, is also a matter of perception, Brown and Hall (1999:9) argue that a place that is remote and difficult to reach may be perceived by tourists to have certain qualities symptomatic of its situation, such as natural beauty, quaintness and otherness. Such places are seen as authentics, (Lash, 1990) rich in symbolic representations of the unspoilt, the pristine and the traditional. Lash (1995) also makes a powerful case to show that it is this otherness which creates attraction. Thus, as Blomgren and Sorensen (1998) propose, the attractiveness of rurality relies on the subjective interpretation of such symbols. Anderson (2000) argues that peripheral spaces have moved from outlying production zones to become areas which are consumed in their own right. He argues that it their very "otherness", non-industrial, distance and an absence of core activities, which creates value in the consumer's eye. One problem with image and motivation to visit, is the fragility of symbolic otherness. (Pearce, 1982) considers appropriate images as transitory, but ones insulated from 
danger. Meethan (2001) talks of trust in a destination; trust in it measuring up to its image. He makes the salient point that the elimination of risk and issues of safety appear as prime factors in choice of destination. Cavlek (2002) points out that peace, safety and security are the primary conditions for the tourism development of a destination. He also notes (2002:479) how "nothing can force them to spend a holiday in a place they perceive as insecure". Indeed, Sonmez and Graef (1998:120) argue that if the destination choice is narrowed down to two alternatives which promise similar benefits, the "one that is safe from threat- is likely to be chosen". Pearce (1988) suggests that concern with personal security is a major factor in the decision-making process through which individuals make their travel choices. Drabek (2000) notes how the effects of crisis ripples out to areas where no such problem exists (Cavlek, 2002). Cavlek (2002) suggests that government warnings to potential tourists always have strong psychological effects, thus creating a major impediment to selling holidays, even to parts of the country still entirely safe. After the Foot and Mouth epidemic started the media contributed to the overall gloom with reports and graphical representations of burning pyres and closures; "national and international images of foot and mouth crisis did most to deter tourists" (Ireland and Vetier, 2002:16) Many Americans were convinced that foot and mouth was contagious BSE, the degenerative human disease (www.hotelresource.com, 2002) Moreover, the portrayal of the Prime Minister in a yellow boiler suit apparently fighting the disaster was not helpful.

Yet as Leaf, (1995) noted, crises have become integral to business activity, but that tourism, in particular, suffers more than any other. Faulkner and Vikuluv (2001) propose that all destinations face the prospect of either a natural or a human-induced disaster. In particular, Cavlek (2002) suggests that government warnings to potential tourists always have strong psychological effects, thus creating a major impediment to selling holidays, even to parts of the country still entirely safe. Arguing that the market for tourism is fragile, Gonzalez-Herrero and Pratt (1998) see tourist travel as a dispensable luxury. Blake and Thea Sinclair (2003) similarly argue that tourism demand is particularly sensitive to security and health concerns. Thus the marketing of tourism products and services depends largely on the degree of perceived risk that potential tourists are willing to bear. Tourism demand presents a higher elasticity index per level of perceived risk than any other industry because of the benefits consumers ascribe to its products. Thus far we have explored the importance of image in motivating tourism. We have demonstrated that the "otherness" of rurality is a key mechanism for attracting tourists. This otherness, we have argued, is an incomplete social construction, driven by globalisation but dependent upon a positive impression of local place. We have also noted how perceptions of risk, real or imagined, like the images themselves, can act to reverse the attraction and turn it into a repelling force. Moreover, as Cole (1995) points out, disasters have their most severe impacts on isolated localities and small or marginal communities.

\section{Rural small business planning}

In peripheral rural areas, small business is the norm. Indeed, the important business sectors consist of small businesses. In tourism, more than three quarters of Britain's tourism organisations have a turnover of less than $£ 250,000$ a year (Frisby, 2002). Of these businesses, approximately half are situated in remote locations. Smallbone and North (1996) note how the relentless decline of rural traditional industries has created a need for the new jobs arising from new and existing small firms in the service sectors, such as tourism, as well as in manufacturing. Morrison (1998:192) points out that in the tourist accommodation sector, owner operators account for some $85 \%$ of establishments but she also notes the typical weakness of such small firms. When combined with the characteristics of peripheral destinations, such as seasonality, low occupancy rates, "the challenges to successful business

development are accentuated". Nonetheless, tourism, especially small firm tourism, remains central to rural development (Briedenhann and Wickens, 2003) 
Small businesses in rural places are part of the community (Spillan and Hough, 2003) and "often strive to put something back into this community" (Band,1999:12). Although crucial to rural community, small businesses are much more fragile than large. They may lack expertise and management skills and require more extensive advice because of the very nature of their smallness. Because of their heterogeneous nature they require a large amount of different types of support agencies. The main business support is provided by public agencies (53\%) and collective agencies (includes trade and professional organisations) $34 \%$. Interestingly, Bennet et al, (2003) note that only $24 \%$ of non-farm businesses generally require any information on planning support. Support and advice are normally available to large organisations in the shape of a board of directors, experienced managers and a hierarchy. Outside day-to-day management, rural small firms may lack the knowledge to deal with change. Many small businesses do not have the time or resources to implement plans and follow and live very much hand to mouth; "too much month left at the end of the money", (Broome and Toll, 2003:1). The viability of small businesses may depend on their ability to identify and respond to trends and opportunities (North and Smallbone, 1996: Smallbone et $a l, 1999)$ presented and threatened by their external environment, yet smaller firms have little ability to shape their macro-environment (Smallbone et al 1999). Moreover in times of crisis, there may be a lack of some sort of planning or "due process" to cope with a turbulent environment where crisis and disaster lurk around every corner. Vaessen and Keeble (1995) argue that many owner managers have to develop strategies to overcome the constraints presented by the environment. "Successful firms may be those that recognise potential threats and through adjustment convert them into opportunities" (North and Smallbone, 1996: 157). Owner managers in small resilient enterprises will show characteristics of cost minimisation, adaptability and resilience through reduced management and personnel. Indeed the small micro business "often forms part of a composite pluriactive household" (Bennett et al, 2003:67) that gives it a certain resilience through a recourse to multiple incomes.

Rural small businesses require flexibility, self sufficiency and less reliance on outside contractors (North and Smallbone, 1996). They cannot externalise their various functions due to their size and remoteness. Planning and strategy are often more implicit than explicit, so that leadership and management skills become extra important. Although the benefits of planning in small firms is contentious (Anderson and Atkins, 2002), Barrington and Greening (1999) identified that successful firms engaged in formal planning and that those that failed, did not. Significantly, they also recognised that successful firms also required outside sources of assistance to help facilitate the planning process. A number of studies have established a relationship between planning and small firm performance. (Braker, Keats and Demon, 1999; Schenk and Schroder, 1993). Bong and Rinholm (1989) and Rowe and Madique (1988) found that planning is an important factor in small business performance. Garnier (1990) identified effective small business firms as those that planned, were flexible, participative and adaptive. Barrington and Greening (1999) found that flexibility was found to have a positive influence on managing growth and performance relationship, whereas environmental turbulence was found to have a negative effect on small businesses achievement.

Crisis management receives little attention in the small business and a crisis event may have to occur before crisis planning becomes a real concern (Spillan and Hough, 2003). The liability of newness and the fragility of smallness are at their greatest in times of crisis and disaster. Yet, crisis, broadly defined, is highly probable, so that all small businesses will eventually be confronted with some type of crisis or disaster. The relevant question seems to be not whether a crisis/disaster will occur, but what kind and when (Copanigro, 2000; Kane, 1993). The ability of the business to manage the crisis successfully can mean the difference between survival and disaster and even life and death (Fink, 1986; Offer 1998). The case for having a disaster plan is strong; $50 \%$ of all businesses who do not have one, either explict or implicit, do not survive and $90 \%$ will fail within two years of the disaster (Perdone 1997, in Spillan and Hough, 2003). 
Tourism in Peripheral areas and Foot and Mouth: the effects.

Tourism in peripheral Grampian

We studied two peripheral areas, Grampian and Cumbria. Cumbria was affected directly with a large number of affected cases but Grampian only indirectly, as it did not have one case during the out break and was more than 150 miles from the nearest case in the South West of Scotland. Grampian is an integral part of the Scottish tourism industry. Tourism is Scotland's most important industry, injecting $£ 2.5$ billion into the economy annually (www.scotexchange.net 2002). It is the 4th biggest employer, employing 193,000, some 8\% of the workforce. In 1995 the UK ranked $4^{\text {th }}$ in the top 10 tourist destinations in Europe, with 23.7 million arrivals (De Vaal, 1997). However, inbound tourist statistics show that only 1.9 million of these United Kingdom visitors came to Scotland (www.staruk.org.uk, 2002), with that figure dropping to 1.5 million in 2001 (Tourism Attitudes Survey 1999). This decrease is blamed on the effects of the September $11^{\text {th }}$ terrorist attack and Foot and Mouth disease. 2002 did however, experience increased visits to Scotland by UK residents, with visits being up by $10 \%$ on 2001 (McKay, 2003). Grampian is the north east shoulder of Scotland with a tourist product primarily focused on scenery and castles. Heritage and history play a major part in tourist attraction; seeing historic house and castles is important for 8 out of 10 visitors. Grampian's attractions currently range from outdoor activities, natural and built heritage to adventure and theme parks (Electric Scotland .com, 2002). It is an area with a mainly peripheral structure with poor roads and a large rural community not dissimilar to Cumbria. It also contains some unique tourist attractions and wonderful scenic beauty comparable to the North West of England. However Aberdeen and Grampian visitor numbers fell by $13.1 \%$ from 140,743 in 2001 to 122,255 during the same period in 2002 (www.scotexchange.net). This drop was confirmed by the local tourist board, at $-12.8 \%$, it was the $2^{\text {nd }}$ lowest level in the country. Most of these effects may be directly attributed to the effects of Foot and Mouth.

Tourism in peripheral Cumbria

Cumbria is devoted to tourism and includes the Lake District National Park and the Hadrian's Wall World Heritage Site and has recently been awarded, after a rigorous assessment Green Globe Destination Status. (http://www.golakes.co.uk 2003). It is a relatively remote area composed of sparsely populated rural sectors with some minor concentrations of populations and many small businesses. The Lake District itself offers a wonderful rural experience with a plethora of cultural events, museums and galleries. It is dominated by small owner managed businesses and the wealth is retained in the local economy and thus supports other industries. However it has been directly affected by foot and mouth and other threats since 2001 and there was a marked decrease in visitor numbers.

Foot and Mouth Disease in Peripheral areas.

Foot and Mouth disease is one of the most contagious animal diseases, although most affected adult animals will recover within two weeks, the drop in yields could have enormous economic impact. It has few effects on humans. Nonetheless, the UK government policy of slaughtering affected or at risk herds had an enormous impact on Britain's countryside. The first cases of Foot and Mouth disease (since 1967) were confirmed on the $10^{\text {th }}$ of February 2001. Within 2 weeks the disease had spread to a large number of cases. After peaking in 
April/May numbers tailed off to October 2001. As Anderson (2003) noted, a total of 2026 cases of the disease were identified but a total of over 4 million animals were culled during the crisis. Media attention during the crisis focussed dramatically on the agricultural community, showing the destruction of livestock and the closure of farms across the county, but the impact was experienced by the tourist industry. Some support was provided in both areas both by the Government and other Agencies, but the usefulness (Bennet et al, 2003) and the limited uptake through the myriad of requirements to qualify (BBC 2001) has been seriously questioned.

\section{Foot and Mouth in Cumbria}

Cumbria was directly affected by Foot and Mouth as $44 \%$ of all confirmed cases happened in this county (Ward et al, 2002). Cumbria's main industries are agriculture and tourism and tourism was affected just as badly as agriculture. As Ireland and Vetier (2002:6) put it; " it is...evident that demand failure among tourists has a severe impact on the British tourism industry." The BBC News website (April 2001) dramatically described the devastation and fear of the unknown future for the farmers of Cumbria saying; "Cumbria is holding its breath, not just in dread of future outbreaks, but also because of the smell of the burial sites." Television dramatised the extreme actions taken by the government and the effect on peoples' lives. Television coverage of the Foot and Mouth epidemic detailed every case and scare within Cumbria. This television coverage scared many potential tourists away from the countryside; many areas that had no contact with the outbreak suffered because of the media messages given. Ireland and Vetier (2002:1) argued that; "Exaggerated media reporting of a crisis can be as damaging as inept Government policy." Many of the tourism businesses within Cumbria closed because of the dramatic reduction of visitors within the area. Although considerable efforts to try and rebuild the businesses by extra advertising and property upgrading, tourist numbers were still poor.

The following Table 1 shows the drop in numbers experienced by tourism businesses due to the Foot and Mouth epidemic. The trips refer to the summer months of June to September 2000- 2002. The table demonstrates that, of the four representative locations, Cumbria was the worst effected with the largest drop in visitor numbers.

Tourism trips in England

\begin{tabular}{|l|l|l|l|}
\hline Summer trips: & $\begin{array}{l}\text { All tourism } \\
\text { trips 2000 }\end{array}$ & $\begin{array}{l}\text { All tourism } \\
\text { trips 2001 }\end{array}$ & $\begin{array}{l}\text { All tourism trips } \\
2002\end{array}$ \\
\hline & Million & Million & Million \\
\hline England & 64.9 & 55.5 & 63.0 \\
\hline Cumbria & 2.3 & 1.8 & 1.8 \\
\hline Yorkshire & 6.0 & 4.4 & 5.8 \\
\hline London & 9.1 & 7.7 & 8.0 \\
\hline
\end{tabular}

Table 1, adapted from Staruk 2003

Foot and Mouth caused a decrease in tourists so great, that all tourism businesses within the area were affected. A large number of the Cumbria attractions were shut down for at least three months. Many of these never reopened. As well as the closure of businesses, the loss in tourism numbers reduced turnover within the area; many people lost their jobs because businesses couldn't afford to support themselves, let alone pay wages, nearly all business investment stopped. The effects were also felt for more than a season by the majority of the tourism businesses. (Ward et al, 2002). 
Table 2 shows the drop in employment numbers in Cumbria between 2000-2001. The businesses include hotels, restaurants, tour operators and cultural activities, all of which rely greatly on tourism within small rural areas. Job losses of more than $25 \%$ were experienced. Lee and Harold (1999) identified that incidents can also disrupt the supply and distribution chain for service.

Employment in Cumbria

\begin{tabular}{|l|l|l|}
\hline & $\begin{array}{l}2000 \\
\text { Jobs }\end{array}$ & $\begin{array}{l}2001 \\
\text { Jobs }\end{array}$ \\
\hline Tour operator & 655 & 549 \\
\hline Hotel & 9,633 & 6,843 \\
\hline Restaurant & 5,816 & 4,409 \\
\hline Cultural activity & 850 & 720 \\
\hline
\end{tabular}

Table 2 (adapted from staruk, 2003)

From the above it is clear that Foot and Mouth had a major impact on rural tourist industry. However, it is not yet clear what role planning had, if any, in ameliorating these impacts. Our research questions therefore focus on this aspect.

\section{Methodology}

Our sample frames were drawn from tourist businesses in Grampian and Cumbria. The Grampian sample of 180 businesses was drawn from a sample frame provided by Dunn and Bradstreet. The Cumbrian sample, 170 businesses, was selected by choosing one in five from a list taken from the official Cumbria Tourist Board Guide (2002). The Grampian sample, the main locus of our study, was surveyed twice. The first Survey A, was carried out in April 2001 at the height of the outbreak and had 85 responses (47\%). The second Survey B was carried out in March 2003 and had 60 responses, (33\%), 18 others were returned uncompleted. The Grampian surveys were intended to provide data to allow us to compare the anticipated with the real effects. The Cumbrian survey, C was carried out in February 2003 and contained a number of identical or similar questions to the Grampian survey. We had a response of 70 , giving a $39 \%$ response rate. In the surveys many of the questions were open ended to allow respondents to enlarge on the data.

\section{Data and discussion}

The characteristics of our samples are shown in Table 3. Small firms, reflecting the rural structure were predominant. Interestingly a greater percentage of larger businesses responded in the second survey in Grampian which may mean that more survived or had grown in the intervening period.

\begin{tabular}{|l|l|l|l|l|l|}
\hline \multicolumn{1}{|c|}{ Survey } & $\begin{array}{c}\text { Business Type by } \\
\text { Size }\end{array}$ & \multicolumn{1}{|c|}{$\mathrm{N}$} & $\begin{array}{c}\text { \% of } \\
\text { total }\end{array}$ & $\begin{array}{c}\text { Professional } \\
\text { Body } \\
\text { Membership } \\
\%\end{array}$ & $\begin{array}{c}\text { Customer } \\
\text { Type: } \\
\text { Tourist } \\
\%\end{array}$ \\
\hline A, Grampian, Apr 01 & Micro <6 & 66 & 78 & 57 & 36 \\
\hline (total $\mathrm{n}=180$ ) & Larger $>5$ & 19 & 22 & $67(.066)$ & $39(.065)$ \\
\hline $\mathbf{B}$, Grampian Apr 03 & Micro <6 & 39 & 65 & 62 & 26 \\
\hline (Total $\mathrm{n}=180)$ & Larger $>5$ & 21 & 35 & $86(.3)$ & $50(.042)$ \\
\hline C, Cumbria Feb,03 & Micro <5 & 50 & 71 & 66 & 93 \\
\hline (total $\mathrm{n}=170)$ & Larger $>4$ & 20 & 29 & $58(.031)$ & $75(.1)$ \\
\hline
\end{tabular}


Table 3, Characteristics of the samples

\section{Notes:}

Survey A,B and C Business Types are by size: number of F/T staff.

Figures in Brackets are the significance confidence levels.

Customer Types are Leisure Tourists other types are Business

Tourist

Survey A and B took place in Grampian at the height of the disease and could be expected to reflect the worst expectations of the impact. We also expected these prognoses to reflect the general gloom created by the vivid and dramatic media portrayal (Ireland,2002), which may suggest that even the tourism suppliers were overly influenced by the negative perspective. The results shown in table 4 below confirms our expectations and show the extent of business reduction and other effects anticipated and experienced in Grampian and that experienced in Cumbria.

Table 4, The General effects of the disease in Grampian: 2001,2003 and differences (all $\%)$.

\begin{tabular}{|c|c|c|c|c|c|c|c|c|}
\hline $\begin{array}{l}\text { Type } \\
\text { (Size) }\end{array}$ & $\begin{array}{l}\text { Cancellations } \\
\text { Anticipated }>10\end{array}$ & $\begin{array}{l}\text { Business } \\
\text { Decrease }\end{array}$ & $\begin{array}{l}\text { Reduced } \\
\text { Profit }\end{array}$ & $\begin{array}{l}\text { Staff } \\
\text { Cuts }\end{array}$ & Closure & $\begin{array}{l}\text { Extent of } \\
\text { Impact>year }\end{array}$ & $\begin{array}{l}\text { Supply } \\
\text { Yes(Y) }\end{array}$ & $\begin{array}{l}\text { Product } \\
\text { (Y) }\end{array}$ \\
\hline \multicolumn{9}{|c|}{ Survey A: Grampian 2001} \\
\hline$<6$ & $60(12)$ & $69(14)$ & 70 & 42 & \multicolumn{2}{|l|}{21} & 36 & 23 \\
\hline$>5$ & $48(.13)$ & $50(.003)$ & $49(.1)$ & $11(.01)$ & \multicolumn{2}{|l|}{$5(.002)$} & $41(.1)$ & $\begin{array}{l}14 \\
(.003\end{array}$ \\
\hline \multicolumn{9}{|c|}{$\begin{array}{c}\text { Survey B: Grampian } 2003 \\
\text { Cancellations } \\
\text { Actual }\end{array}$} \\
\hline$<6$ & $71(10)$ & $46(10)$ & 38 & 7 & 8 & 24 & 8 & 18 \\
\hline$>5$ & $60(.1)$ & $43(.3)$ & $42(.1)$ & $19(.2)$ & $0(.2)$ & $24(.07)$ & $9(.06)$ & $9(.1)$ \\
\hline \multicolumn{9}{|c|}{ Difference between the two Surveys. } \\
\hline$<6$ & +11 & 23 & 32 & 35 & 13 & 28 & 28 & 5 \\
\hline$>5$ & +12 & 07 & 07 & +08 & 05 & 14 & 32 & 5 \\
\hline
\end{tabular}

Notes: all \%

- Cancellations are those anticipated over the immediate tourism season.,Survey A and actually experienced,Survey B

- Supply (Y) indicates that the business supply was affected

- Product $(\mathrm{Y})$ indicates that the Product to customers was affected.

- Figures in Brackets are the significance confidence levels.

- Figures in brackets for cancellations and business decrease are for the smaller businesses with more than $70 \%$ decrease in these criteria.

In Survey A the view was very pessimistic, more than half our Grampian respondents anticipated cancellations and large decreases in the business and profits. Some $25 \%$ expected to have to lose staff and a significant number anticipated closure of their business. Most expected the impact to last for some considerable time. Taken by size, the smaller micro businesses, representing $78 \%$ of the population, anticipated suffering more in all areas apart from supply, where they may have had more flexibility. 
Survey B measured the real impact in Grampian and shows that, whilst the impact was greater on the micro businesses, the picture was not as clear as in Survey A. It is worth noting that $10 \%$ of our original sample had gone away. This could be partially attributed to the impact or simply business churn. Overall cancellations at $64 \%$ of bookings reflect a major loss of business. Nonetheless, we note that actual business volume decrease was "only" $44 \%$, suggesting that some replacement visitors were found. This view corresponds to the study by Phillipson et al (2003). Taken by size, the results demonstrate that the major impacts of decrease in cancellations, business volume and effect on product offered were clearly worse for the smaller businesses with some $8 \%$ experiencing closure. The other effects were only marginally different with $24 \%$ of both types experiencing effects for more than one year. The results shown in survey B are not as bad as were anticipated in survey A and reflect an overly pessimistic anticipation of effects in 2001.

\section{The Cumbria survey}

The Cumbrian survey (Table 5) is a snapshot of data collected two years after the epidemic. The data show a dramatic reduction in visitor numbers with a 96 and 93\% in each size category indicating a decrease in visitor numbers. Some $98 \%$ and $88 \%$ respectively experienced a "loss of business" of more than $25 \%$. When asked about specific percentages of "loss of business", about $20 \%$ in both sizes of business identified an actual loss of business of "more than 50\%". Staff cuts were highest in the larger types of business. A very large percentage in both types experienced the effects for more than a year, whilst a large number, especially in the larger businesses still experiencing the effects at the present time. (Ward et al,2003) A greater number of small businesses owners suffered from depression during the outbreak, this may be because of the responsibility carried. Interestingly, nearly all the businesses situated in Cumbria on reflection, considered that the F and $\mathrm{M}$ epidemic had the worst effect on their organisation when compared to B.S.E. and 9/11.

\begin{tabular}{|l|l|l|l|l|l|l|l|}
\hline $\begin{array}{l}\text { Type } \\
\text { (Size) }\end{array}$ & $\begin{array}{l}\text { Visitor Number } \\
\text { Decrease }\end{array}$ & $\begin{array}{l}\text { Loss of } \\
\text { Business } \\
(>25 \%)\end{array}$ & $\begin{array}{l}\text { Staff } \\
\text { Cuts }\end{array}$ & $\begin{array}{l}\text { Extent of } \\
\text { Impact>year }\end{array}$ & $\begin{array}{l}\text { Extent of } \\
\text { impact } \\
\text { (still feeling) }\end{array}$ & $\begin{array}{l}\text { Depression } \\
\text { F and M } \\
\text { Effect: }\end{array}$ \\
\hline Survey C: Cumbria 2003 & 96 & 98 & 20 & 46 & 28 & 94 \\
\hline$<5$ & $93(.09)$ & $88(.1)$ & $40(.2)$ & $53(.2)$ & $40(.4)$ & 14 & $0(.21)$
\end{tabular}

Table 5, The General effects of the disease in Cumbria 2003 (all\%).

\section{Notes: all \%}

The $\mathrm{F}$ and $\mathrm{M}$ epidemic was compared to the effects of BSE and 9/11.

$<5$ means, 5 or more employed in the business

\section{The effect of planning}

Tables 7, a, b and c shows how the businesses prepared and acted to mitigate against the effects. In Survey A, (table 7a) a greater number of larger businesses had a plan and considered it to be effective, with many considering that the Government supported them. The smaller business group had less plans, but more that had considered them to be effective; more believed that the Government supported them and a similar number had potential for support from their membership of a professional body. Table $7 \mathrm{~b}$ identifies that greater effects were experienced by the smaller businesses, although the businesses that had plans considered them to be more effective. Table $8 \mathrm{~b}$ a much smaller number of businesses had a plan and were supported, although the smaller businesses seemed to have more planning in place, but less potential for support, although both types of business considered they had received some level of government support. They did however make more changes and alterations to their 
processes than the larger businesses. This is reflected in the effects being similar and less severe in both types of business in Survey B. Also the results of Survey B were real and not anticipated. In Table 8c the smaller businesses were generally much better prepared and although the effects were similar in both sizes of business, staff cuts and length of effects. Although a large number in both types of business considered that the Government offered support, very few considered it to be effective.

\begin{tabular}{|l|l|l|l|l|}
\hline $\begin{array}{l}\text { Size } \\
\text { Employ, }\end{array}$ & Contingency Plan & Effective & $\begin{array}{l}\text { Government } \\
\text { supported }\end{array}$ & Membership \\
\hline$<6$ & 25 & 18 & 25 & 57 \\
\hline$>5$ & $52(.1)$ & $07(.12)$ & $0(.02)$ & $66(.03)$ \\
\hline
\end{tabular}

Table 8a: Responses, Survey A

\begin{tabular}{|l|l|l|l|l|l|}
\hline $\begin{array}{l}\text { Size } \\
\text { Employ' }\end{array}$ & Contingency Plan & Effective & $\begin{array}{l}\text { Government } \\
\text { supported }\end{array}$ & Membership & Alter/changes \\
\hline$<6$ & 17 & 03 & 21 & 58 & 26 \\
\hline$>5$ & $10(.1)$ & $0(.23)$ & $19(.1)$ & $86(.12)$ & $18(.07)$ \\
\hline
\end{tabular}

Table 8b: Responses, Survey B

\begin{tabular}{|l|l|l|l|l|l|l|}
\hline $\begin{array}{l}\text { Size } \\
\text { Employ' }\end{array}$ & Personal Plan & $\begin{array}{l}\text { How plan } \\
\text { effective }\end{array}$ & $\begin{array}{l}\text { Government } \\
\text { Support/effective }\end{array}$ & Membership & Accept help & Help effective \\
\hline $0-4$ & 58 & 60 & $88 / 15$ & 66 & 72 & 70 \\
\hline$>4$ & $34(.2)$ & $24(.1)$ & $100 / 0(.2)(.4)$ & $44(.1)$ & $75(.12)$ & $45(.003)$ \\
\hline
\end{tabular}

Table 8c: Responses, Survey $\mathrm{C}$ All in \%

Government Support is \% felt supported

Effective is \% felt effective.

\section{Conclusions}

From these data, we conclude that the effects of foot and mouth disease on peripheral tourism business was considerable. The Grampian longitudinal studies indicate that although bad, these effects were not quite as bad as anticipated. In both areas the impact was both immediate, manifest in dramatic drops in volume of business, profitability and reductions of staff numbers. It was also long term, a large number of businesses taking almost a year to recover. However the most significant result in our data is the demonstration that firms who planned appeared to weather the crisis better.

In comparing the larger and smaller we note that small firms anticipated a much worse effect than actually experienced. Given that the larger firm group did experience worse effects, it seems reasonable to conclude that small firms, in the prodromal stage of crisis were quickest to recognise the impending crisis and best at reacting. We can conclude that they responded more effectively. It is not clear exactly how planning operated. It may have been that the smaller scale of operations made planning easier, both to formulate and to implement. It may also have been that the inherent flexibility of smaller firms allowed them to change direction more rapidly. However our data does support the argument that if the prodromal stage of 
crisis is attended it may not become catastrophe. From a theoretical perspective, we note the crucial role of communication. In this instance, the impact of the media presentations of foot and mouth exacerbated a bad situation into a national crisis. Globalisation, the new economy of space and sign conspired, through media, to produce the foot and mouth crisis for the tourism industry. The portrayal of "otherness" is symbolically dependent upon an arcadian image. The confrontation to this imagery with media pictures of smoking cattle funeral pyres resulted in repelling visitors to places where no such pyres existed! This seems to confirm that perceptions, rather than facts or real circumstances, create the disastrous effects of catastrophe. It is very difficult to image what sort of planning, at the macro level, could alleviate the impact of sensationalism.

In terms of the implication arising from our survey, there seems no doubt that there were real problems with planning and environmental shocks at national level as all the reports (Anderson, Defra, CIEHO,2002) articulated. However although the effects were felt both directly and indirectly, peripheral businesses seemed to be prepared and coped effectively using their own or the support provided. However the evidence suggests that organisations in peripheral areas seemed to cope better with plans and support in place. Turning to the practical aspects of the impact on small business, it is notable that the impact in Grampian was less severe than anticipated. This difference between potential havoc, anticipated effect and the real total effect can probably best be explained by the agility of small firms to cope with crisis Supply and distribution channels were markedly effected in both small and larger businesses, especially the product in smaller organisations, (Lee and Harold,1999) who generally required and had a more flexible approach.

\section{References:}

Alhemoud, A.M. and Armstrong, E.G., 1996. Image of tourism attractions in Kuwait. Journal of Travel Research 34. 4, pp. 76-80.

Anderson, I., 2002,Foot and Mouth Disease 2001: Lessons to be Learned Inquiry Report, HC888, The Stationery Office, London

Anderson, A.R., 2000, Paradox in the periphery; and entrepreneurial reconstruction?, Entrepreneurship and Regional Development, 12: 91-109

Anderson, A.R., Atkins, M, (2002), Configuration and Reconfiguration- Planning for Uncertainty, Journal of Entrepreneurship and Innovation Management, vol.2, 4/5, pp 406-23

Ashworth, G. and Goodall, B., 1988. Tourist images: marketing considerations. in Goodall, B. and Ashworth, G., Editors, 1988. Marketing in the tourism industry The promotion of destination regions, Routledge, London, pp. 213-238

Baum, T. 1996, Images of Tourism Past and Present, International Journal of Contemporary Hospitality Management, 8(4) 25-30

Baum, T. and Lundthorp. S. 2001, Seasonality in Tourism, Elsevier Science Ltd, Oxford.

Bigne, J.E., Sanchez, M.I., San, J, 2001, Tourism image, evaluation variables and after purchase behaviour: inter-relationship, Tourism Management , 22(6), 607-616

Blomgren, K.B., Sorensen, A., 1998, Peripherality- factor or feature? Reflections on peripherality in tourist regions, Progress in Tourism and Hospitality Research, 4, p 319-336

Briedenhann, J., Wickens, E., (2003) Tourism routes as a tool for the economic development of rural areas- vibrant hope or impossible dream? Tourism Management, in press

Brown, F. and Hall, D. 2000, Tourism in Peripheral Areas, Channel View Publications, Great Britain.

Brown, F., Hall, D, 1999, The Paradox of Periphery, introduction to Paradox of Periphery, eds., Report 15, Research Centre of Bornholm, Nexo, Denmark

Brunt, P., Mawby, R. and Hambly, Z., 2000. Tourist victimisation and the fear of crime on holiday. Tourism Management 21 4, pp. 417-424. 
Carter, S., 1998, Tourists' and travellers' social construction of Africa and Asia as risky locations, Tourism Management, 19(4) 349-358

Cavlek, N., 20002, Tour operators and destination safety, Annals of Tourism Research, 29(2) 478-496

Crompton, J.L. and Ankomah, P.K., 1993. Choice set propositions in destination decision's. Annals of Tourism Research 20, pp. 461-476

Crompton, J.L., 1979, Motivations for pleasure vacations, Annals of Tourism Research, 6: 408-424.

Crompton, J.L., 1979. An assessment of the image of Mexico as a vacation destination and the influence of geographical location upon that image. Journal of Travel Research 14, 4, pp. 18-23.

Dann, G., 1996, The people of the tourist brochures, in Selwyn, T. (ed.) The Tourist Image: Myth and myth making in tourism, Wiley, Chichester.

Dann, G.M.S., 1981, Tourist motivation: an appraisal, Annals of Tourism Research, 8: 187424

Davidson, R. 1998, Travel and Tourism in Europe, $2^{\text {nd }}$ Edn, Addison Wesley Longman Ltd, Edinburgh.

De Vaal, D. 1997, A Survey of Continental European Visitor Attractions, Delotte And Touche Consulting Group, UK, p.12-40

Drabek, T., 2000, Emergency Management, principles and Applications for Tourism, Hospitality and Travel Management, Federal Emergency Management Agency, www.fema.gov/emi/edu/higher.htm

Fakeye, P.C. and Crompton, J.L., 1997. Images differences between prospective, first-time and repeat visitors to the Lower Rio Grande valley. Journal of Travel Research 302 , pp. 10-16.

Faulkner, B.,Vikulov, S., 2001, Katherine, washed out one day, back on track the next: a postmortem of a tourist disaster, Tourism Management, 22, 331-344

Galloway, G., 2002, Physcographic segmentation of park visitor markets; evidence for sensation seeking, Tourism Management 23, 581-596.

Gartner, W.C., 2000. Tourism image: attribute measurement of state tourism products using multidimensional scaling techniques. Journal of Travel Research 28 2, pp. 16-20

Goossens, C. 2000, Tourism information and pleasure motivation, Annals of Tourism Research, 27(2) 301-321

Gunn, C., 1972, Vacationscape: Designing tourist regions, Bureau of Business Research, University of Texas, Austin, TX.

Harvey, D, 1989, The Condition of Postmodernity, Blackwell, Oxford

Hunt, J.D., 1998. Image as a factor in tourism development. Journal of Travel Research 13 , pp. 1-7.

Johnson, P. and Thomas, B., 1995. The analysis of choice and demand in tourism. In: Johnson, P. and Thomas, B., Editors, 1995. Choice and demand in tourism, Mansell, London, pp. 1-12.

Kent, P., 1996. People, places and priorities: opportunity sets and consumers holiday choice. In: Ashworth, G. and Goodall, B., Editors, 1996. Marketing tourism places, Routledge, London, pp. 42-62

Kneafsey, M., (2001) Rural Cultural Economy, tourism and social relations, Annals of Tourism Research, 28(3) 762-783

Kumar, K., 1995, From post-industrial to post-modern society, Blackwell, Oxford.

Lash, S., Urry, J., 1994, Economies of Signs and Space, Sage, London

Mansfeld, Y., 1982. From motivation to actual travel. Annals of Tourism Research 19, pp. 399-419.

Mathieson, A., Wall, G., 1982, Tourism: Economic, physical and economic impacts, Longman, New York.

Mc Kay, D. 2003, Future of Tourism to be Debated at Abertay, The Press and Journal, 13 January, Aberdeen. 
Morrison, A., (1998) Small firm co-operative marketing in a peripheral tourism region, International Journal of Contemporary Hospitality Management, 10(5) 191-197

North, D., Smallbone,, D., 2000, The Innovativeness and Growth of Rural SMEs During the 1990s. Regional Studies, 34(2) 145- 158

Owen, R.E., Botterill, D., Emanuel, L., Foster, N., Gale, T., Nelson, C., Selby, M., 1999, Perceptions from the periphery- the experience of Wales, in Brown, F., Hall, D, eds., The Paradox of Periphery, Report 15, Research Centre of Bornholm, Nexo, Denmark

Pearce, P.L. 1982, The Social Psychology of Tourist Behaviour, Pergamon, Oxford.

Pearce, P.L., 1988. The Ulysses factor: Evaluating visitors in tourist settings, Springer, New York.

Phelps, A., 1999. Holiday destination image-the problem of assessment: an example developed in Menorca. Tourism Management 7 3, pp. 168-180.

Phillipson, J., Bennet, K., Lowe, P., Raley, M., (2003) Adaptive responses and asset strategies: the experience of rural micro-firms and Foot and Mouth disease, Journal of Rural Studies, in press

Pike, S., 2002, Destination Image analysis- a review of 142 papers from 1973 to 2000, Tourism Management, 23, 541-548

Reid, L., Reid, S. 1993, Communicating tourism supplier services; building repeat visitor relationships, Journal of Travel and Tourism Marketing, 2, 3-19

Smallbone, D., North, D., Kalantaridis, C., (1999) Adapting to peripherality; a study of small rural manufacturing firms in Northern England, Entrepreneurship and Regional Development, 11, 109-127

Sonmez, S.F. and Graefe, A.R., 1998. Influence of terrorism, risk on foreign tourism decisions. Annals of Tourism Research 25 1, pp. 112-144

Sonmez, S.F., 1998. Tourism, terrorism, and political instability. Annals of Tourism Research 25 2, pp. 416-456.

Tiefenbacher, J.P., Day, F.A., Walton, J.A., 2000, Attributes of repeat visitors to small tourist-orientated communities, Social Science Journal, 37(2) 299-308

Tiefenbacher, J.P., Day, F.A., Walton, J.A., 2000, Attributes of Repeat Visitors to Small

Tinsley, R., Lynch, P., (2001) Small tourism business networks and destination development, Hospitality Management, 20, 367-378

Urry, J., 1995 Consuming Places, Routledge, London

Urry, J., 1990, The Tourist Gaze, Sage, London

Wanhill, S., 1997, Peripheral area tourism- a European perspective, Progress in Tourism and Hospitality Research, 3, 47-70

References Available Online.

Facts About Cumbria 2003, Cumbrian Tourist Board, [online] www.golakes.co.uk (Accessed 23 ${ }^{\text {rd }}$ July 2003)

Key Facts of Tourism for Cumbria2000-2002, Available World Wide Web:

(www.staruk.org.uk, 2003 (Accessed 20 ${ }^{\text {th }}$ July 2003)

Know your Market. 1999, Tourism Attitudes Survey 1999 [online] Available World Wide Web: www.scotexchange.net

(Accessed $12^{\text {th }}$ January 2003)

Media Office, 2003, Scotland's Most Important Industry [online] Available World Wide Web: www.scotexchange.net

(Accessed $14^{\text {th }}$ January 2003) 
Other Publications.

Bennet et al,2003

Ireland,M.,Vetier,L.,2002,The reality and mythology of the Foot and Mouth Disease crisis in Britain: Factors influencing tourist destination choice, Working Paper.

Ward et al,2002

APA Journal 2002, Planning for disasters,68 (4) p 453

\section{References}

Cole, S. (1995) Lifelines and Livelihood; a social accounting matrix approach to calamity preparedness, Journal of Contingencies and Crisis Management, 3(4) 228-240

Okumus, F., Alintay, M., Arasli, H., (2003) The impact of Turkey's economic crisis of February 2001 on the tourism industry in Northern Cyprus, Tourism Management, in press

Burnett, J., (1998) A Strategic approach to managing crisis, Public Relations Review, 24(4), $478-488$

Gonzalez-Herrero, A., Pratt, C.B. (1998) Marketing Crises in Tourism: Communication Strategies in the United States and Spain, Public Relations Review, 24(1) 83-97

Faulkner, B., (2001) Towards a framework for tourism disaster management, Tourism Management, 22, 135-147 
Davis, H., Walters, M., (1998) Do all crisis have to become disasters? Risk and risk mitigation, Disaster Prevention and Management, 7(4) 396-400

Baudrillard, J., (1998) The Consumer Society, Sage, London

Lerbinger, O. (1997) The Crisis Manager: Facing Risk and Responsibility, Erlbaum Associates, New Jersey.

Beck, U., Risk Society: Towards a New Modernity, Sage, London

Harvey, D., (1980) The Condition of Postmodernity, Blackwell, Oxford

Blake, A., M. Thea Sinclair, (2003) Tourism Crisis Management, US response to September 11, Annals of Tourist Research, 3094) 813-832

Selbst, P., (1978), cited in Faulkner, (2001) Towards a framework for tourism disaster management, Tourism Management, 22, 135-147

Kash, T., Darling, J., (1988) Crisis Management: Prevention, diagnosis and intervention, Leadership and Organizational Development Journal, 19(4) 179-186

Fink, S., (1986) Crisis Management; Planning for the inevitable, American Management Association, New York

Stafford, G., Yu, L., Amroo, A.K., (2002) Crisis Management and Recovery, Cornell Hotel and Catering Administration Quarterly, October, 27-40

Carter, W.N., (1991) Disaster Management: A disaster manager's handbook, Asian Development Bank, Manila

Ritchie, B.W., (3003) Chaos, crises and disaters: a strategic approach to crisis management in the tourism industry, Tourism Management, in press 